International Journal of Trend in Scientific Research and Development (IJTSRD)

Volume: 3 | Issue: 3 | Mar-Apr 2019 Available Online: www.ijtsrd.com e-ISSN: 2456 - 6470

\title{
Air-Water System Design using Revit Mep for a Residential Building
}

\author{
B. Shushma1, M. Uday Bhaskar², N. Balaji², G. Srujan Yadav² \\ ${ }^{1}$ Assistant Professor, ${ }^{2}$ Student \\ 1,2Department of Mechanical Engineering, Guru Nanak Institute of Technology, Rangareddy, Telangana, India
}

\begin{abstract}
How to cite this paper: $\mathrm{B}$. Shushma | M. Uday Bhaskar | N. Balaji | G. Srujan Yadav "Air-Water System Design using Revit Mep for a Residential Building" Published in International Journal of Trend in Scientific Research and Development (ijtsrd), ISSN: 24566470, Volume-3 I Issue-3, April 2019, pp.1220-1224, URL: https://www.ijtsrd.c om/papers/ijtsrd23 314.pdf

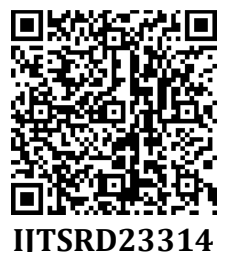

Copyright (C) 2019 by author(s) and International Journal of Trend in Scientific Research and Development Journal. This is an Open Access article distributed under the terms of the Creative Commons

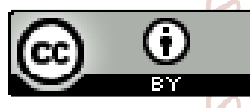
Attribution License (CC BY 4.0) (http://creativecommons.org/licenses/ by $/ 4.0$ )

\section{INTRODUCTION}

In air-water systems both air and water are used for providing required conditions in the conditioned space. The air and water are cooled or heated in a central plant. The air supplied to the conditioned space from the central plant is called as primary air, while the water supplied from the plant is called as secondary water. The complete system consists of a central plant for cooling or heating of water and air, ducting system with fans for conveying air, water pipelines and pumps for conveying water and a room terminal. The room terminal may be in the form of a fan coil unit, an induction unit or a radiation panel. Even though only one conditioned space is shown in the schematic, in actual systems, the air-water systems can simultaneously serve several conditioned spaces

Types of systems

The basic types are

1. All-water systems,

2. All-air systems,

3. Air-water systems,

4. Heat pump.

\section{ABSTRACT}

In this project we discussed the study and performance of air conditioner, air refrigeration and water conditioner system in a single unit. The main objective of this project is to develop the multifunctional system which can provide refrigeration effect, cold water and air conditioning effect with in regular air or distributing the both conditioned air and water to the terminal units installed in the spaces for which the basic plan is given by civil department and the basic design is done by using REVIT MEP software. The air and water are heated or prim air to distinguish it from the recirculated or secondary room air. By using the peak cooling load values obtained in the heating and cooling load the ton of refrigeration values for individual and total area is residential building.

KEYWORDS: Air-water system, heating and cooling loads, REVIT MEP, etc.,

\begin{tabular}{|c|c|c|}
\hline $\begin{array}{c}\text { Local Systems } \\
\begin{array}{c}\text { Variable } \\
\text { refrigerant } \\
\text { volume(VRV) }\end{array}\end{array}$ & $\begin{array}{c}\text { All-Air System } \\
\text { Variable air } \\
\text { volume(VAV) }\end{array}$ & $\begin{array}{c}\text { Air-Water } \\
\text { Systems }\end{array}$ \\
\hline $\begin{array}{c}\text { Chilled } \\
\text { beams (CB) }\end{array}$ \\
\hline Split units & $\begin{array}{c}\text { Constant } \\
\text { volume (CV) }\end{array}$ & $\begin{array}{c}\text { Fan coil } \\
\text { unit (FCU) }\end{array}$ \\
\hline & Displacement & $\begin{array}{c}\text { Water } \\
\text { Source } \\
\text { ventilation (DV) } \\
\text { Pumps }\end{array}$ \\
\hline
\end{tabular}

Circuit diagram

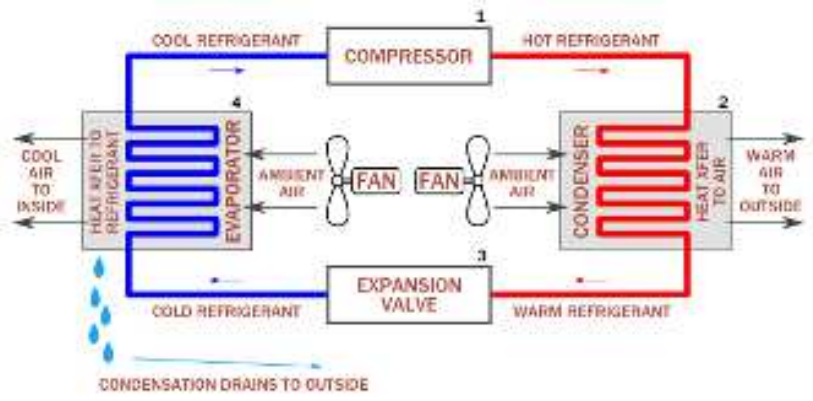

Fig 1: Layout diagram of a Air conditioning system2: Layout diagram of a Air-water system 


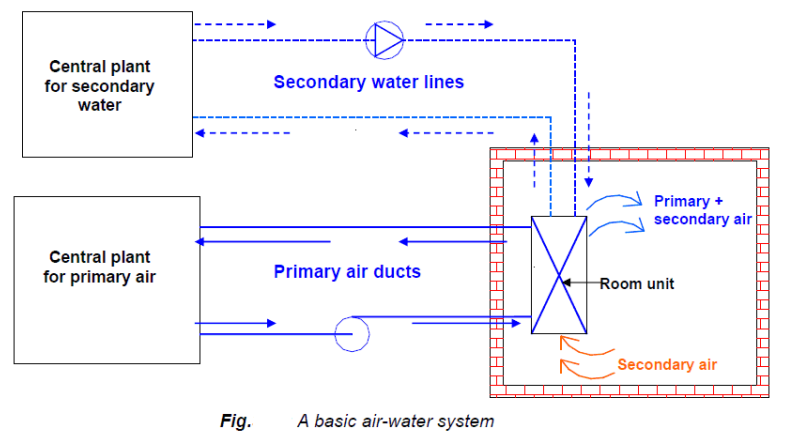

Fig 2: Layout diagram of a Air-water system

\section{REFRIGERENT}

A refrigerant is a mixture or a substance usually in a liquid form used in a refrigeration cycle. Refrigeration is the process of exchanging heat from one place to the other place in a controlled space conditions. In various cycles the process undergoes the phase changes from a liquid state to a gas state and back again. Many working fluids have been used for such purposes.

\section{Different types of refrigerents}

$>$ Halocarbons

$>$ Isotropic refrigerants.

$>$ Zoetrope refrigerants.

$>$ Inorganic refrigerants like carbon dioxide, ammonia, water and air.

$>$ Hydrocarbo refrigerants.

\section{LITERATURE SURVEY}

Pete Jacobs (2003) explains The Small HVAC System Design Guide that provides design guidance on how to improve the installed performance of small packaged rooftop HVAC systems in commercial buildings. The document is targeted at architects, engineers, and design/build contractors involved in the design of small packaged rooftop systems for commercial building applications. It includes information and advice on overall building design practices to minimize HVAC loads, unit selection and sizing, distribution and control system design, commissioning, and operations and maintenance. By applying the integrated design principles in this document, the energy consumption and costs of buildings with small HVAC systems can be reduced by $25 \%$ to $35 \%$. Impacts on building first costs are minimized through a combination of load avoidance strategies designed to reduce the size and cost of the HVAC system, with simple paybacks of about 0.2 to 2.4 years. Along with integrated design, other design strategies suggested in this document focus on establishing and maintaining efficient operation of systems as they are installed in the field. Problems with equipment and controls (economizers, fan controls, thermostat programming), in-situair flow and fan power, refrigerant charge, and operation/maintenance practices that can lead to poor system performance are addressed. together with knowledge of the physical configuration of the HVAC components and their relationships in systems.

N Fernandez, MR Brambley and S Katipamula et all. (2009) made studies and explained self-correction algorithms developed in the Self- Correcting Heating, Ventilating and Air-Conditioning (HVAC) Controls project funded jointly by the Bonneville Power Administration and the Building Technologies Program of the U.S. Department of Energy. The algorithms address faults for temperature sensors, humidity sensors, and dampers in air- handling units and correction of persistent manual overrides of automated control systems. All faults considered create energy waste when left uncorrected as is frequently the case in actual systems. The algorithms are presented in the form of a highly integrated set of flowcharts and include four processes are accomplished in the algorithms using passive observational fault detection, proactive tests for fault isolation (when needed), additional proactive testing for fault characterization for some faults, and formulation of a mathematical compensation for the fault to correct for the presence of the fault and permit continued operation of equipment. The processes flowcharts express the algorithms as rules based on fundamental physical and engineering principles

Andersson et al. designed heating and cooling loads for a sample commercial building at different orientations, using a development version of the building energy analysis computer program BLAST. They identified that the total loads were found to be higher for north than south orientation except in extreme southern latitudes of the U.S.

Omar et al. calculated the hourly cooling load due to different kinds of wall, roof and fenestration using transfer function method (TFM). The output of this method was compared with the well-known Carrier program and the results were acceptable. In the case of cooling load, when the results were compared with the ASHRAE examples, some differences were noticed due to wall and roof. They also studied the effects of changing the wall color on cooling load.

Adnan Shariah et al. studied the effect of the absorptance of external surfaces of buildings on heating, cooling and total loads using the TRNSYS simulation program. Two types of construction materials, namely heavy weight concrete block and light weight concrete were used in the simulation. They also calculated the effects of the absorptance on energy loads for insulated buildings. They reported that, for uninsulated buildings, as the absorptance was changed from one to zero, the total energy load decreased by $32 \%$, while for insulated buildings, it decreased by $26 \%$ in Amman. Whereas the decrease was about $47 \%$ for uninsulated and $32 \%$ for insulated buildings in Aqaba

\section{METHODOLOGY}

\section{Design of the building:}

The basic design of the residential building is done using the REVIT MEP software based on the plan given by civil department. According to the plan the design of FCU (fan coil unit) is prepared and the heating and cooling load values are obtained for each and every space of the designed building and the values are mentioned in the following tables given below. 
International Journal of Trend in Scientific Research and Development (IJTSRD) @ www.ijtsrd.com eISSN: 2456-6470

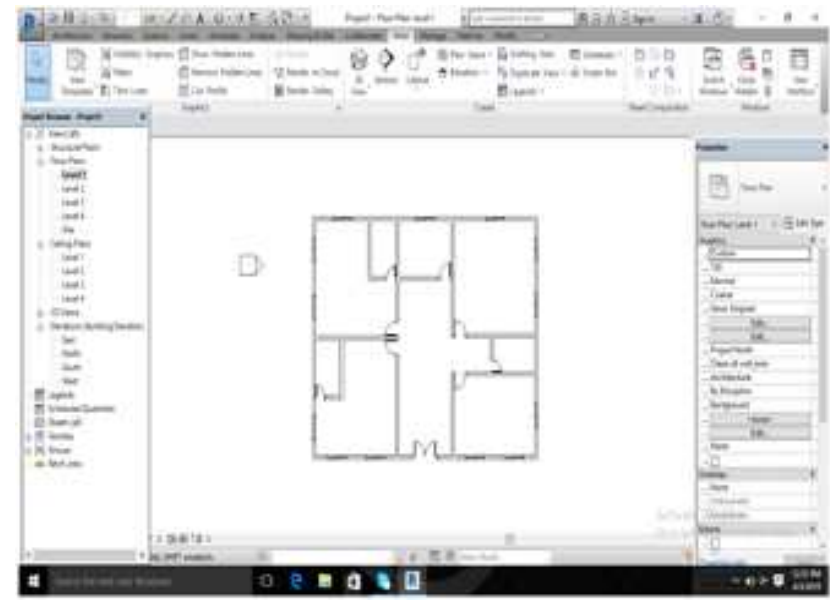

Fig 3: Layout of the building

The basic plan is drawn in the above fig. 3 based on the design parameters and the ceilings and roofs are mentioned in the below fig. 4 and fig. 6 and the layout is shown.

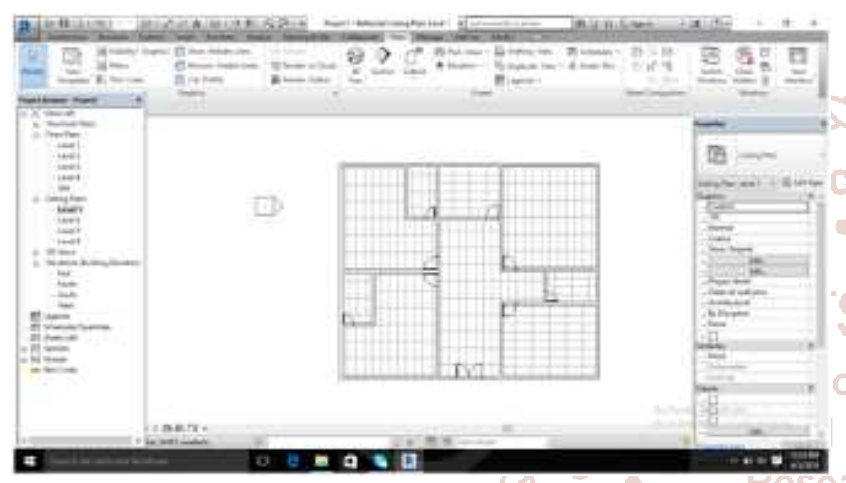

Fig 4: Layout after fall ceiling

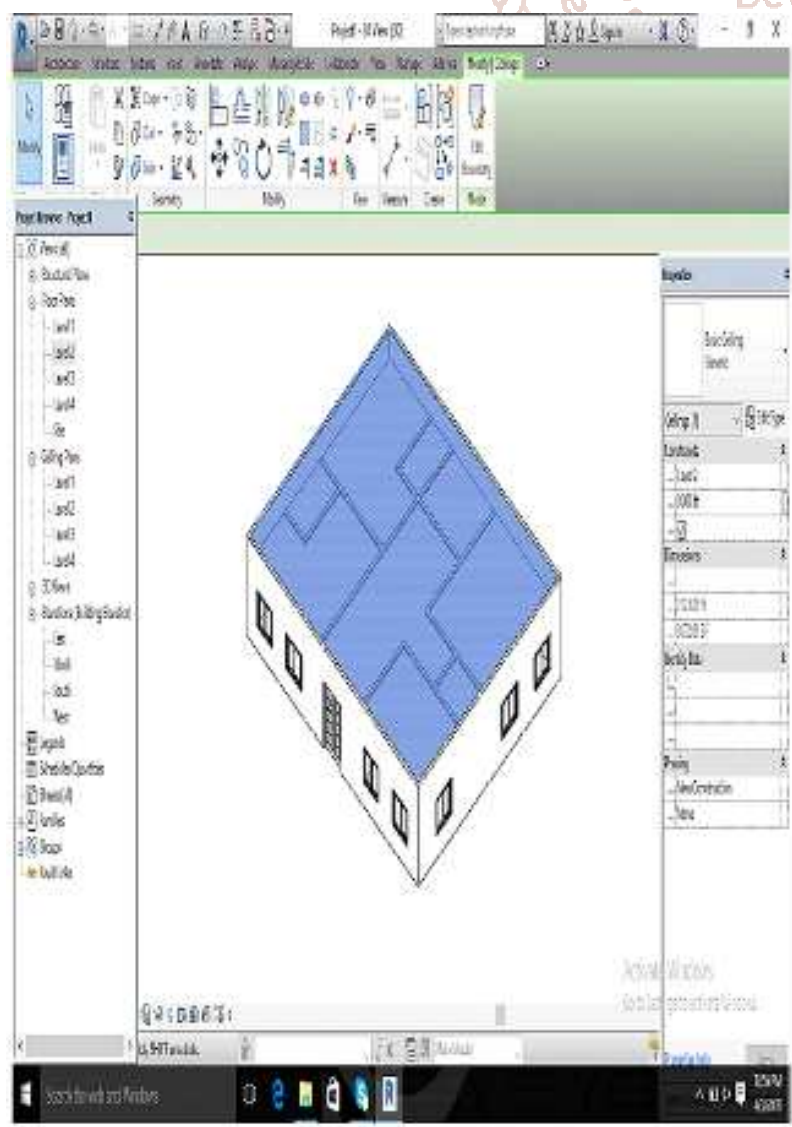

Fig 5: Layout after ceiling

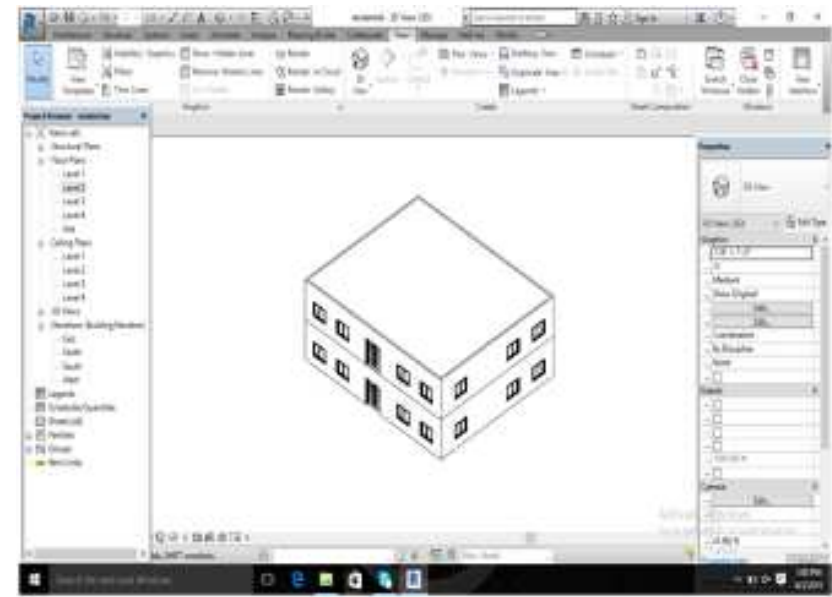

Fig 6: 3D view of the building

In fig 7. and fig.8 the heating and cooling load calculations is calculated by spacing following by zone spacing for individual spaces and by selecting the heating and cooling load the analytical values are obtained. The below fig.7 shows heating and cooling load values only for ground floor and fig. 8 shows the heating and cooling load values for combined ground and first floor.

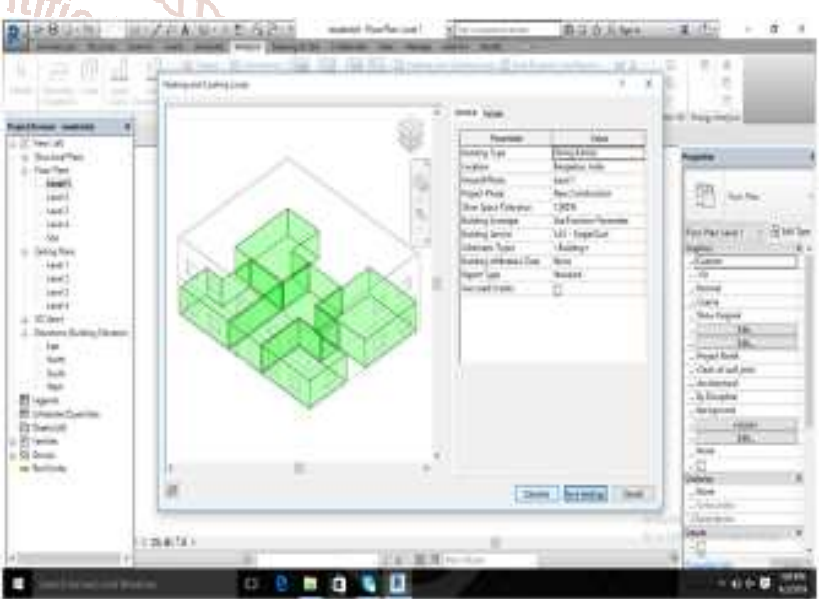

Fig 7: Heating and cooling load analysis for ground floor

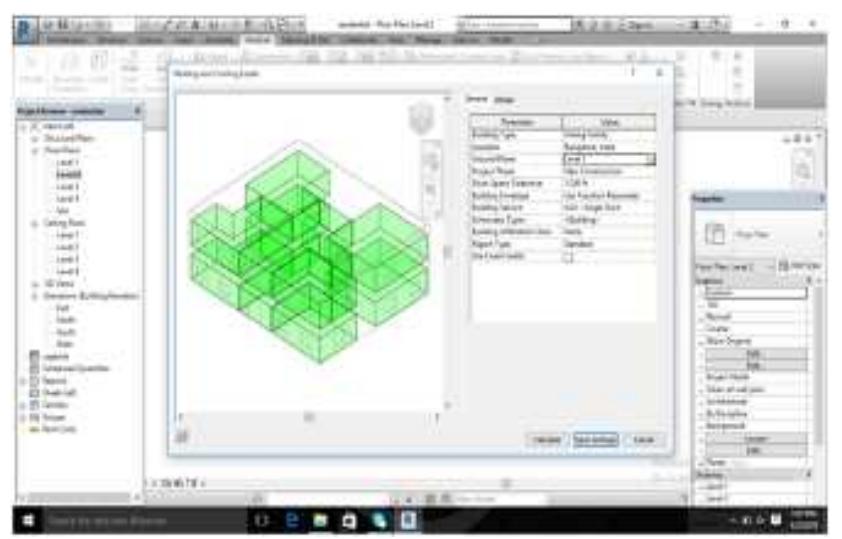

Fig 8: Heating and cooling load analysis for ground and first floor

\section{CALCULATIONS}

From the analysis of the building for ground and first floor the heating and cooling load values are obtained which are shown in below table 1 and table 2 for respective floor. 
International Journal of Trend in Scientific Research and Development (IJTSRD) @ www.ijtsrd.com eISSN: 2456-6470

Table no.1 Heating and cooling load values of the ground floor

\begin{tabular}{|c|c|c|c|c|c|c|}
\hline $\begin{array}{c}\text { Space } \\
\text { Name }\end{array}$ & $\begin{array}{c}\text { Area } \\
\text { (SF) }\end{array}$ & $\begin{array}{c}\text { Volume } \\
\text { (CF) }\end{array}$ & $\begin{array}{c}\text { Peak Cooling } \\
\text { Load (W) }\end{array}$ & $\begin{array}{c}\text { Cooling } \\
\text { Airflow (L/s) }\end{array}$ & $\begin{array}{c}\text { Peak Heating } \\
\text { Load (W) }\end{array}$ & $\begin{array}{c}\text { Heating Airflow } \\
\text { (L/s) }\end{array}$ \\
\hline 1 Space & 438 & $3,736.33$ & 2,981 & 128.1 & 0 & 0.0 \\
\hline 2 Space & 438 & $3,736.33$ & 2,981 & 128.1 & 0 & 0.0 \\
\hline 3 Space & 606 & $5,165.81$ & 4,122 & 177.1 & 0 & 0.0 \\
\hline 4 Space & 521 & $4,442.87$ & 3,545 & 152.3 & 0 & 0.0 \\
\hline 5 Space & 368 & $3,138.54$ & 2,504 & 107.6 & 0 & 0.0 \\
\hline
\end{tabular}

Table no.2 Heating and cooling load values of the first floor

\begin{tabular}{|c|c|c|c|c|c|c|}
\hline $\begin{array}{c}\text { Space } \\
\text { Name }\end{array}$ & $\begin{array}{c}\text { Area } \\
\text { (SF) }\end{array}$ & $\begin{array}{c}\text { Volume } \\
\text { (CF) }\end{array}$ & $\begin{array}{c}\text { Peak Cooling } \\
\text { Load (W) }\end{array}$ & $\begin{array}{c}\text { Cooling } \\
\text { Airflow (L/s) }\end{array}$ & $\begin{array}{c}\text { Peak Heating } \\
\text { Load (W) }\end{array}$ & $\begin{array}{c}\text { Heating Airflow } \\
(\mathrm{L} / \mathrm{s} \text { ) }\end{array}$ \\
\hline 6 Space & 438 & $3,736.33$ & 11,157 & 641.8 & 1,292 & 138.0 \\
\hline 7 Space & 438 & $3,736.33$ & 11,276 & 648.6 & 1,288 & 137.7 \\
\hline 8 Space & 606 & $5,165.81$ & 14,199 & 816.8 & 1,598 & 170.8 \\
\hline 9 Space & 521 & $4,442.87$ & 13,044 & 750.3 & 1,486 & 158.8 \\
\hline 10 Space & 368 & $3,138.54$ & 9,501 & 546.5 & 1,093 & 116.8 \\
\hline
\end{tabular}

By using the peak cooling load values obtained from the analysis the ton of refrigeration is calculated by converting load values into tons mentioned in below table $3 \& 4$.

Table no.3 The air flow rate and TR for the ground floor are listed below.

\begin{tabular}{|c|c|c|c|c|}
\hline SL NO & FLOOR & ROOM NAME & FLOW (L/s) & TONNES \\
\hline 1 & GROUND & SPACE 1 & 128.1 & 0.84 \\
\hline 2 & GROUND & SPACE 2 & 128.1 & 0.84 \\
\hline 3 & GROUND & SPACE 3 & 177.1 & 1.17 \\
\hline 4 & GROUND & SPACE 4 & 152.3 & 1.0 \\
\hline 5 & GROUND & SPACE 5 & 107.6 & 0.70 \\
\hline
\end{tabular}

Table no.4 The air flow rate and TR for the first floor are listed below.

\begin{tabular}{|c|c|c|c|c|}
\hline 6 & FIRST & SPACE 6 & 641.8 & 3.17 \\
\hline 7 & FIRST & SPACE 7 & 648.6 & 3.20 \\
\hline 8 & FIRST & SPACE 8 & 816.8 & 4.0 \\
\hline 9 & FIRST & SPACE 9 & 750.3 & 3.70 \\
\hline 10 & FIRST & SPACE 10 & 546.5 & 2.70 \\
\hline
\end{tabular}

\section{RESULT}

Below results will show the TR values of all the floors and all the rooms

\begin{tabular}{|c|c|c|c|}
\hline SL NO & FLOOR & ROOM NAME & TR \\
\hline 1 & GROUND & SPACE 1 & 0.84 \\
\hline 2 & GROUND & SPACE 2 & 0.84 \\
\hline 3 & GROUND & SPACE 3 & 1.17 \\
\hline 4 & GROUND & SPACE 4 & 1.0 \\
\hline 5 & GROUND & SPACE 5 & 0.70 \\
\hline 6 & FIRST & SPACE 6 & 3.17 \\
\hline 7 & FIRST & SPACE 7 & 3.20 \\
\hline 8 & FIRST & SPACE 8 & 4.0 \\
\hline 9 & FIRST & SPACE 9 & 3.70 \\
\hline 10 & FIRST & SPACE 10 & 2.70 \\
\hline & \multicolumn{5}{|c|}{ TOTAL } & 21.32 \\
\hline
\end{tabular}




\section{CONCLUSION}

From the above calculations the estimated 21.32 TR capacity machine required. For this fan coil unit was used to maintain proper air conditioning. It is suitable for 12000-18000 CFM flow rate and 25-28 TR capacity. In this work the calculated cooling air flow values of each room in each floor and TR values of each room were calculated.

The Capacity of unit required is 21.32 TR approximately but used 25-28 TR machine to avoid the fluctuations in the working.

Based on the obtained cooling air flow values for each room and for all the floors the Duct Design was done by using AUTO_DESK REVIT software. All the diagrams were shown in the civil plan .Thus we can reach to a conclusion that our estimated values are enough to establish the air conditioning system in the specified location. By using HVAC system energy consumption of the building is reduced as possible by avoiding unnecessary losses. This is one of the most well designed and most useful methods in the present day installations.

\section{REFERENCES}

[1] Jacobs, P. 2003. Small HVAC Problems and Potential Savings Reports. P500-03-082A-25, California Energy Commission, Sacramento, CA.

[2] Fernandez, N., M.R. Brambley and S. Katipamula. 2009. Self-Correcting HVAC Controls: Algorithms for Sensors and Dampers in Air-Handling Units, PNNL-19104, Pacific Northwest National Laboratory, Richland, WA.

[3] Andersson,B., Wayne P. and Ronald K., " The impact of building orientation on residential heating and cooling" , Energy and Buildings,1985; 8; 205-224.

[4] Al-Rabghi,O. and Khalid A. , " Utilizing transfer function method for hourly cooling load calculations" Energy Conversion and Management,1997; 38; 319-332

[5] Shariah,A., Bassam S., Akram R. and Brhan T.," Effects of absorptance of external surfaces on heating and cooling loads of residential buildings in Jordan" Energy Conversion and Management,1998; 39; 273-284.

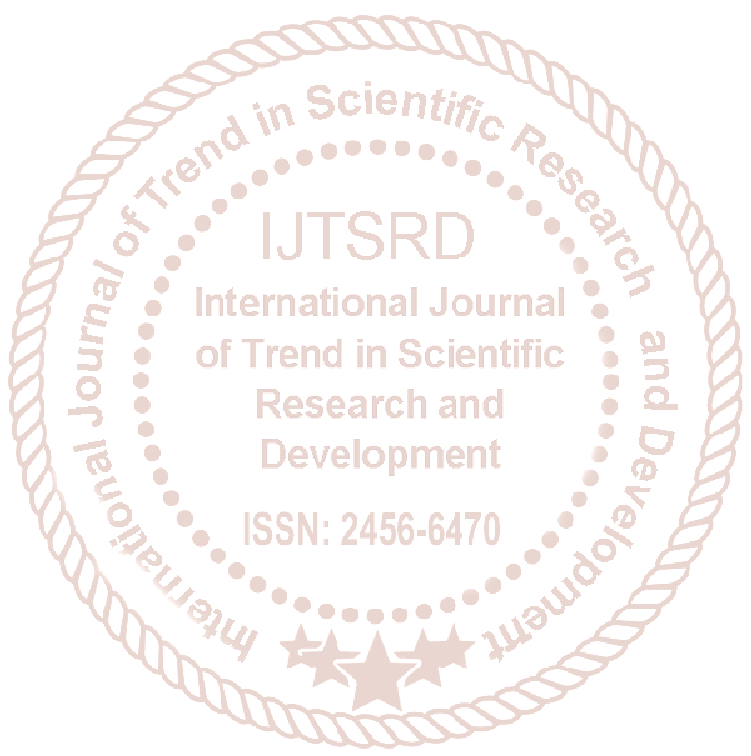

